\title{
Population structure, harvesting rate and regeneration status of four woody species in Kimboza forest reserve, Morogoro region - Tanzania
}

\author{
David Sylvester Kacholi \\ Department of Biological Sciences, Dar es Salaam University College of Education (DUCE), P. O. Box 2329 Dar es \\ Salaam, Tanzania \\ Corresponding Author: kacholi78@yahoo.com
}

\begin{abstract}
Kimboza forest reserve is recognized as an IUCN category IV-habitat and species management area, but the information on population structure, harvesting rate and regeneration status of four commercial woody species, namely; Khaya anthotheca, Milicia excelsa, Pterocarpus angolensis and Dalbergia melanoxylon in the forest are lacking. This study, therefore, aims to fill this gap. A total of five transects were established in the forest whereby within each transect, five nested quadrats of $20 \mathrm{~m} \times 20 \mathrm{~m}$ were placed at $200 \mathrm{~m}$ distance for sampling stems with diameter at breast height $(\mathrm{DBH}) \geq 10 \mathrm{~cm}$ and stumps of the target species. Stems with DBH $<10 \mathrm{~cm}$ were counted in a quadrat of $5 \mathrm{~m} \times 5 \mathrm{~m}$ placed within the big quadrat. The findings show that density of stems \& harvesting rate for Khaya anthotheca, Milicia excelsa, Pterocarpus angolensis and Dalbergia melanoxylon were 4.8 stems ha $^{-1}$ \& 6.6 stumps ha ${ }^{-1}, 12.6$ stems ha $^{-1} \& 3.4$ stumps ha $^{-1}, 16.0$ stems ha $^{-1} \& 2.8$ stumps ha $^{-1}$, and 5.6 stems ha $^{-1} \& 1.2$ stumps ha ${ }^{-1}$, respectively. The DBH class distribution for Khaya anthotheca, Milicia excelsa and Pterocarpus angolensis displayed a good regeneration pattern, however, the last two were interrupted in high size classes. The Dalbergia melanoxylon revealed a poor regeneration pattern. The study recommends that illegal harvest of the species should be controlled, environmental education be provided to locals, and stringent measures be institutionalized against illegal loggers.
\end{abstract}

Keywords: DBH classes, Exploitation rate, Kimboza, Stand density, Tropical forests.

\section{INTRODUCTION}

Tropical forests are biodiversity rich ecosystems in the globe (Myers et al., 2000; Liang et al., 2016), however, deforestation and fragmentation threatens their value (Hill et al., 2011; Popradit et al., 2015). The forests are reported to be lost at an alarming rate. For instance, between 1990 and 2000 as well as 2000 and 2010, the global annual forest loss due to human-induced destructions was $5.2 \times 10^{6}$ ha year $^{-1}$ and $8.3 \times 10^{6}$ ha year $^{-1}$, respectively (FAO, 2010). In Tanzania, an average of 403,350 ha year ${ }^{-1}$ have been lost between 1990 and 2010 (Kideghesho, 2015). The loss is linked to the increase of human population living nearby the forests (FAO, 2010; Burgess et al., 2017). The global statistics show over 800 million people living close the forests are poor and depend entirely on the ecosystems for their livelihood (FAO, 2018). The growth of the population living adjacent the forest ecosystems cause increased demand for more land for agricultural activities, pole and timber for building purposes as well as charcoal and firewood for energy (Riswan \& Hartanti, 1995; Becker et al., 2005). The increased demand exert more pressure towards forest ecosystems, which consequently result to degradation and loss of forest resources (Sharma et al., 2019). About $70 \%$ of the population in the country are poor ruralists that depend entirely on agriculture and forest resources for their livelihoods (FAO, 2010). The dependency has been reported to cause loss of forest expanses in the country (Kacholi, 2013; Kideghesho, 2015). The loss jeopardizes not only forest existence but also valuable timber species and other present life forms (Chaudhary et al., 2016).

Tanzania harbours 33.5 million hectares of forests, whereby $90 \%$ are woodlands, and $53.7 \%$ of the country's forested land is under protection as forest reserves while $12.2 \%$ of the hectares are under participatory forest management (Kideghesho, 2015). The Kimboza forest reserve is among the protected forests of Tanzania that are part of 34 global biodiversity conservation hotspots (Myers et al., 2000). The forest reserve harbors unique fauna and flora and provides habitats for various creatures, such as black and blue monkeys, wild pigs, white colubus, baboons and other species like snake, snails, birds, fish, lizards, butterflies and other diverse species of insects. Also, it harbors blue dwarf gecko called Lygodactylus williamsi Loveridge., which is an endemic lizard species found only on stem of Pandanus tree species. In its small area, the forest reserve possesses very high number of endemic, near endemic and threatened plant species. Endemic species present in Kimboza forest are Ophrypetalum odoratum Diels., Baphia Pauloi Brummitt., Chassalia discolar K.Schum., Epiphyllons liverworts L., Garcinia bifasciculata N. Robson., Necepsia castaneifolia (Baill.) ssp. kimbozensis (A.R.-Sm.) Bouchat. \& J. Léon., Necepsia castaneifolia (Baill.) Pax. ssp. 
kimbozensis A.R.-Sm., Turraea kimbozensis Cheek., Cynometra uluguruensis Harms., Impartiens cinnabarina C. GreyWilson., Pavetta crebrifolia Hiern. var. Kimbozensis (Bremek.) Bradson and Streptocarpus Kimbozanus B.L. Burtt (Temu \& Andrew, 2008).

Moreover, the forest harbors 15 near endemic species, which include Uvariodendron gorgonis Verdc., Amorphophalus stuhlmannii (Engl.) Engl. \& Gerhm., Garcinia semseii B. Verdcourt., Kalanchoe obtuse Engl., Euphorbia quadrialata Pax., Suregada lithoxyla (Pax \& K.Hoffm.) Croizat., Zenkerella egregia J. Léonard., Milletia elongatistyla J.B. Gillett., Isoberlinia scheffleri (Harms) Greenway., Dorstenia hildebrandtii var. hildebrandtii (Engl.), Ixora tanzaniensis Bridson., Kraussia speciosa Bullock., Tricalsia acidophylla Robbrecht., Tricalysia pedicellata Robbrecht., Aningeria pseudoracemosa J.H. Hemsl. (Temu \& Andrew, 2008). Also, it harbors several threatened species such as Khaya anthotheca (Welw.) C.DC., Milicia excelsa (Welw.) C.C. Berg., Pterocarpus angolensis DC. and Dalbergia melanoxylon Guill. \& Perr. (Kacholi et al., 2015). Regardless of rich biodiversity, Kimboza forest reserve is facing anthropogenic pressure whereby the forest resources are illegally harvested by poor rural communities and unfaithful people living adjacent the reserve for their daily livelihoods and commercial drives (Kacholi, 2013). The unsustainable harvest of forest products disrupts the ecosystem and make their future being rather indeterminate.

The unsustainable exploitation occurs due to the fact that most of the forest reserves in the country are inadequately protected (Stuart et al., 1990). For instance, inappropriate and unsystematic management of the Kimboza forest reserve have caused various anthropogenic activities, such as illegal logging, forest fires, mining, charcoaling, and encroachment to take place (Kacholi, 2013). Such human-induced activities contribute to degradation and loss of plant species in any forest ecosystem (Mligo et al., 2011). While unsustainable harvesting of marketable timber species pose challenge to us, data on their population structure, size class distribution and regeneration is lacking (Modest et al., 2011). Taking this situation into reflection, many questions on population structure, exploitation pressure and regeneration status of valuable timber species in the Kimboza forest reserve arises. Therefore, this study aims to provide status on population structure, harvesting rate and regeneration of four valuable timber species, namely, Khaya anthotheca, Milicia excelsa, Pterocarpus angolensis and Dalbergia melanoxylon in the forest reserve. The data from this study are valuable for conserving the species and management of the forest reserve at large.

\section{MATERIAL AND METHODS}

\section{Description of the study area}

Kimboza forest reserve is a protected forest owned by the central government. It is located between $06^{\circ} 59^{\prime}$ and $07^{\circ}$ $02^{\prime}$ 'South and $37^{\circ} 47^{\prime}$ and $37^{\circ} 49^{\prime}$ East at an average elevation of 300-400 $\mathrm{m}$ above the mean sea level and covers an area of 405 ha (Fig. 1). The forest is accessed through the Morogoro - Kisaki road, which is $60 \mathrm{~km}$ long from Morogoro Municipality. It is surrounded by six villages, namely; Uponda to the West, Kiswira to the South West, Mwarazi and Kibangile to the East, Nige to the South and Kilemela to the North. The forest has two vegetation types, wet woodland and lowland vegetation types. The forest is affected by human-induced actions such as pit sawing, tress-passing, illegal logging, medicinal activities, mining activities and beekeeping (Kacholi, 2013). The climate of the Morogoro region is tropical sub-humid with bimodal rainfall system. The long rains start in March and end in May of each year peaking in April, while the short rains start in October and end in December of each year. The mean annual rainfall and temperature in the region is about $740 \mathrm{~mm}$ and $25.1^{\circ} \mathrm{C}$, respectively (Fig. 2) (Kacholi, 2020). Agriculture is the main socio-economic activity in the surrounding villages. Other observed land use practices include livestock keeping, bee keeping, fishing, carpentry, and small scale gold mining.

\section{Data collection}

A survey was conducted to identify habitations of Khaya anthotheca, Milicia excelsa, Pterocarpus angolensis and Dalbergia melanoxylon in the forest reserve. Five transects were established in the forest whereby within each transect, a series of five nested quadrats were placed at $200 \mathrm{~m}$ intervals along transects. A quadrat of $20 \mathrm{~m} \times 20 \mathrm{~m}$ was used for sampling stems with $\mathrm{DBH} \geq 10 \mathrm{~cm}$ and stumps of the target species while a quadrat of $5 \mathrm{~m} \times 5 \mathrm{~m}$ was established within each $20 \mathrm{~m} \times 20 \mathrm{~m}$ quadrat for counting stems with $\mathrm{DBH}<10 \mathrm{~cm}$. Stems and stumps were counted and identified with the help of an experienced local expert, and the DBH of trees with diameters of $\geq 10 \mathrm{~cm}$ were measured and recorded. Wood and bark features were used as criteria for identification of the target species from stumps.

\section{Data analysis}

The density of trees was calculated as number of individuals per unit sampled area (stems $\left.\mathrm{ha}^{-1}\right)$ as shown in equation 1. The harvesting rate was determined by the number of stumps of a species per unit area (stumps ha ${ }^{-1}$ ) as shown in equation 2. The regeneration status of the four tree species were determined using the following size (DBH) class distribution: class 1: 0-10 cm, class 2: $11-20 \mathrm{~cm}$, class 3: $21-30 \mathrm{~cm}$, class 4: 31-40 cm, class 5: 41-50 cm, class 6: 51-60 $\mathrm{cm}$, class 7: $61-70 \mathrm{~cm}$ and class 8: $>70 \mathrm{~cm}$. Single analysis of variances (one-way ANOVA), followed by the post-hoc 
Tukey's Highly Significance Difference (HSD) test were used to test for statistical differences in mean densities and harvesting rate among the studied species using QED statistics software.

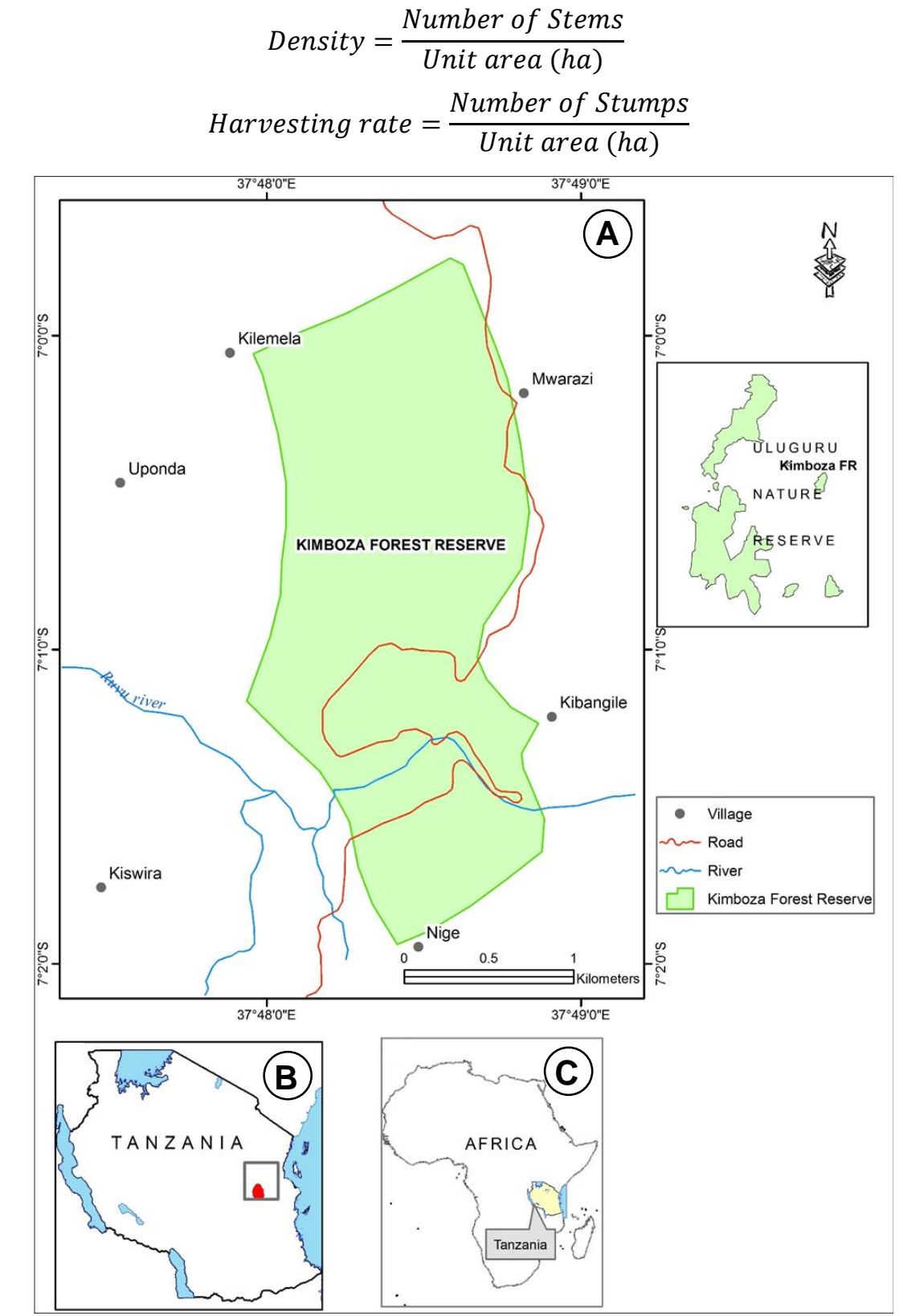

Figure 1. Map of study area: A, Kimboza forest reserve and surrounding villages; B, Location of the forest reserve in Tanzania; $\mathbf{C}$, Location of Tanzania in Africa.

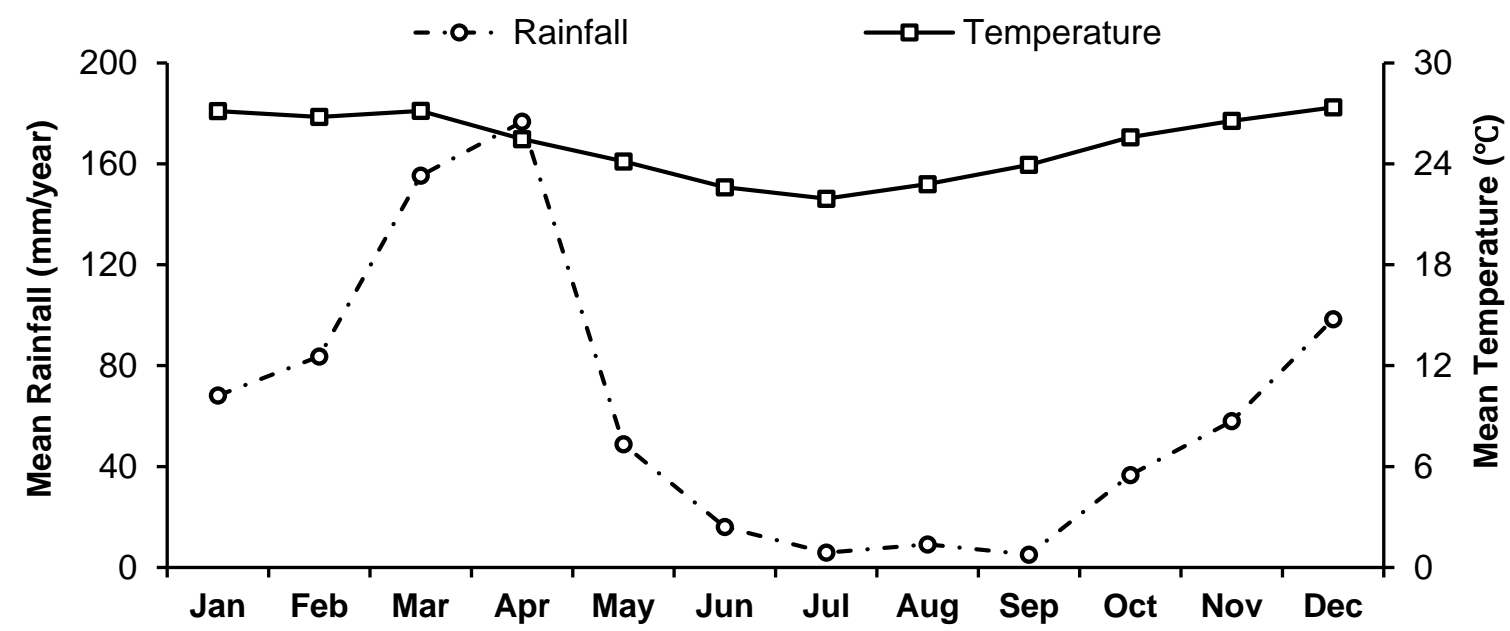

Figure 2. Monthly mean rainfall and temperature of Morogoro region. 


\section{RESULTS}

\section{Density of stems}

The findings revealed that the mean density of the four studied species differed significantly $(\mathrm{F}=154.34, \mathrm{p}<0.05)$. Khaya anthotheca (54.8 stems $\mathrm{ha}^{-1}$ ) and Dalbergia melanoxylon (5.6 stems ha ${ }^{-1}$ ) had considerably higher and lower stems density, respectively. The stems density of Milicia excelsa (12.6 stems ha ${ }^{-1}$ ) and Pterocarpus angolensis (16.0 stems ha ${ }^{-1}$ ) did not differ appreciably (Fig. 3).

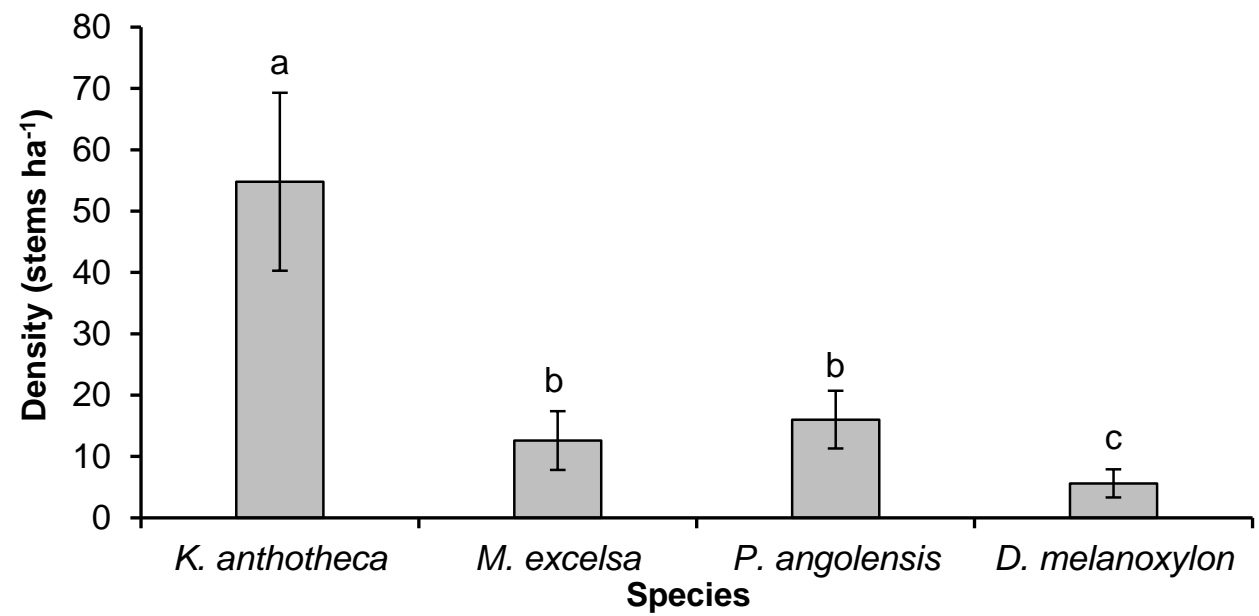

Figure 3. Mean density of the four studied woody species in Kimboza forest reserve. (Tukey's HSD test, $p=0.05$ )

\section{Harvesting rate}

The results revealed that the mean harvesting rate among the four studied species differed considerably $(\mathrm{F}=39.95, \mathrm{p}$ <0.05). Khaya anthotheca (6.6 stumps ha ${ }^{-1}$ ) and Dalbergia melanoxylon (1.2 stumps ha ${ }^{-1}$ ) had significantly higher and lower number harvesting rate, respectively. The harvesting rate of Milicia excelsa (3.4 stumps ha ${ }^{-1}$ ) and Pterocarpus angolensis (2.8 stumps ha ${ }^{-1}$ ) did not differ appreciably (Fig. 4).

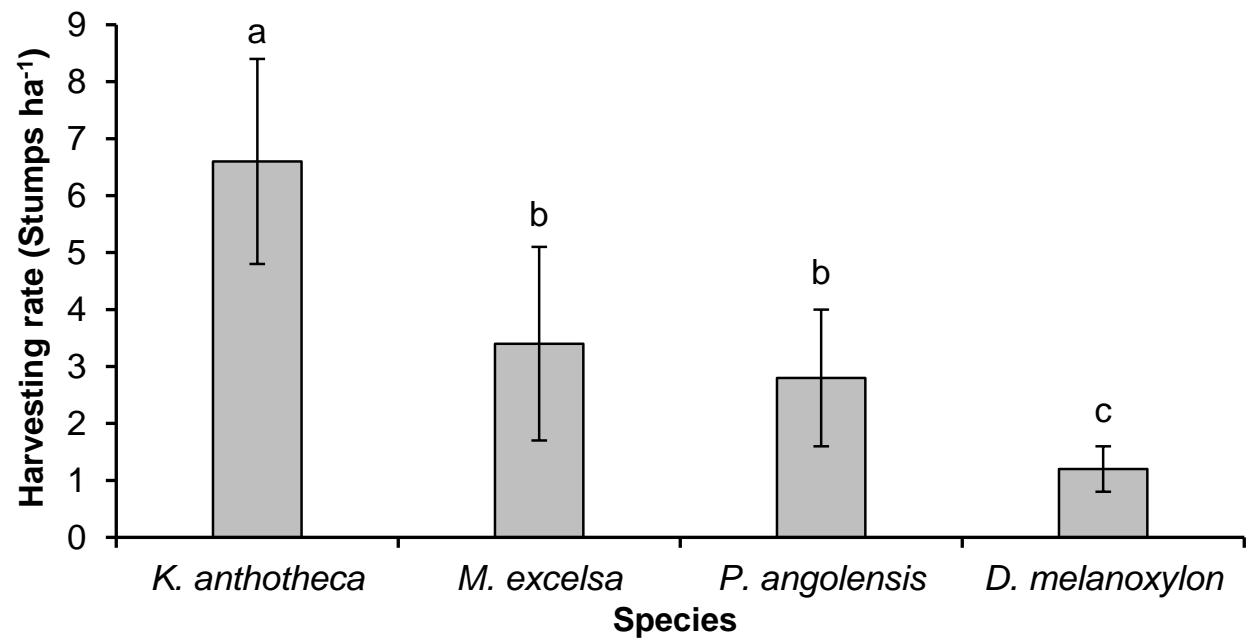

Figure 4. Mean harvesting rate of the four studied woody species in Kimboza forest reserve. (Tukey's HSD test, $\mathrm{p}=0.05$ )

\section{Regeneration status}

The size class distribution of Khaya anthotheca, Milicia excelsa and Pterocarpus angolensis displayed the reverse Jcurve representing good regeneration, however, the latter two species appeared to be interrupted or hampered in the higher DBH classes (Fig. 5). The Dalbergia melanoxylon showed a poor regeneration pattern as it lacked individuals in the lower DBH class (i.e. 0-10 cm), and the regeneration was broken kind-of as only two DBH class $($ i.e. $11-10 \mathrm{~cm}$ and $31-40 \mathrm{~cm}$ ) were represented by individuals (Fig. 5).

\section{DISCUSSION}

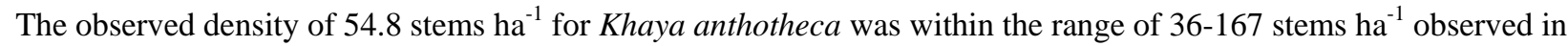
Ituri primary forest, Democratic Republic of Congo for the same species (Makana \& Thomas, 2006). Also, the reverse J-curve (Fig. 2) exhibited by this species suggests that the species has active regeneration as it recruits fairly well and the population structure is stable (Mwavu \& Witkowski, 2009; Mligo et al., 2011). Regardless of the good regeneration pattern and higher density, the species had higher harvesting rate (6.6 stumps $\left.\mathrm{ha}^{-1}\right)$ than other studied species in the 
forest reserve. This suggests that, if illegal logging is not controlled, the species is likely to undergo a decline in density and undoubtedly affect regeneration (Okiror et al., 2012; Borah et al., 2014). Other studies conducted elsewhere (Ahrends et al., 2010; Burgess et al., 2017) reported Khaya anthotheca to be illegally logged for commercial drives. This signifies that Khaya anthotheca is still vulnerable, thus, appropriate conservation and management measures need to be taken to ensure their existence.
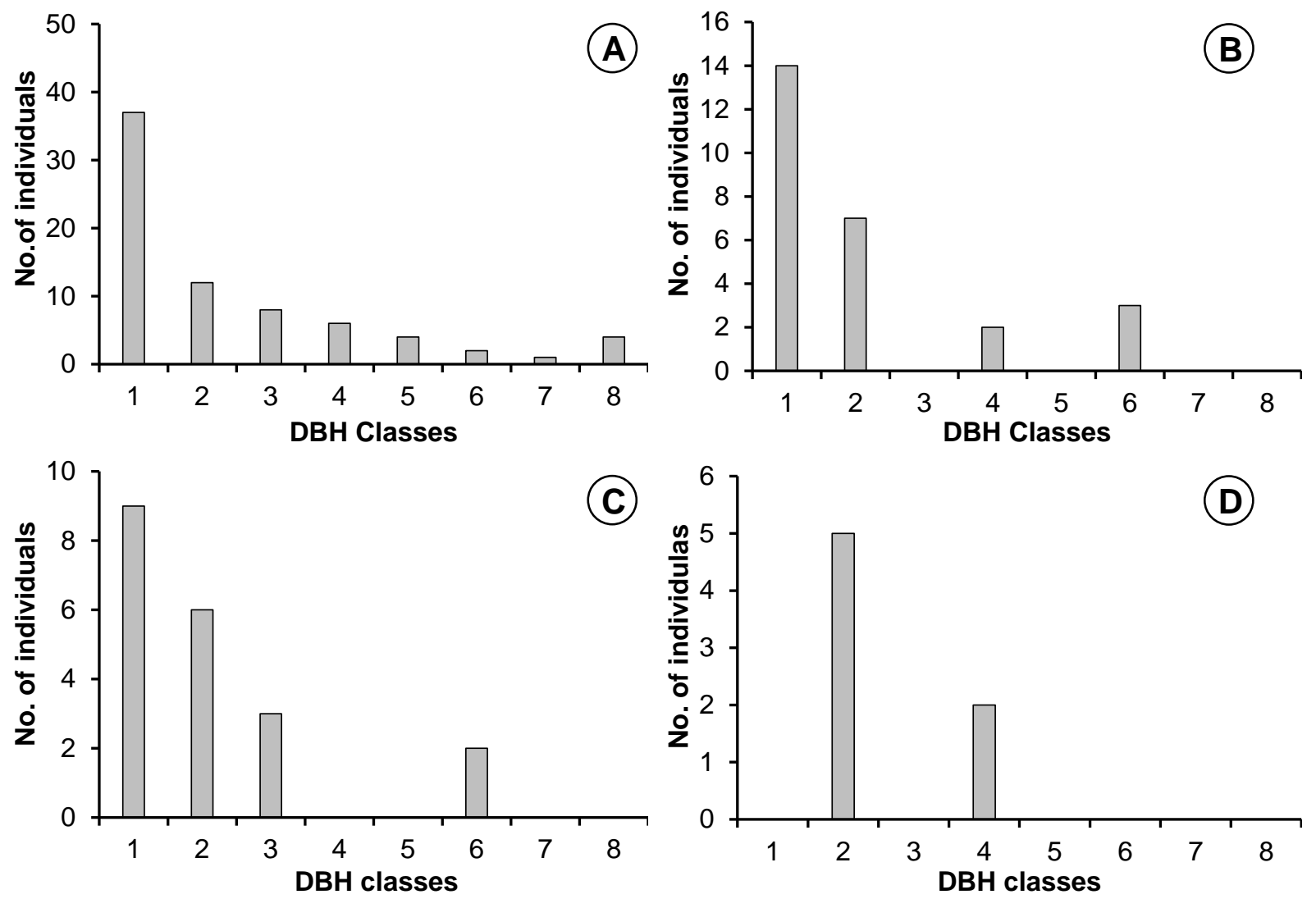

Figure 5. Size class distribution of the four studied woody species in Kimboza forest reserve: A, Khaya anthotheca (Welw.) C.DC.; B, Milicia excelsa (Welw.) C.C. Berg.; C, Pterocarpus angolensis DC.; D, Dalbergia melanoxylon Guill. \& Perr.

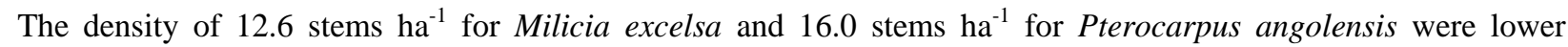
compared to the density of 16.0 stems ha $^{-1}$ recorded in Budongo forest reserve in Uganda (Mwavu \& Witkowski, 2009) and 19.0 stems $\mathrm{ha}^{-1}$ observed in Nguru ya Ndege forest reserve in Morogoro, Tanzania (Modest et al., 2011), respectively. However, the density of Pterocarpus angolensis in the present study is higher than the density of 3.67 stems $\mathrm{ha}^{-1}$ and 13 stems ha ${ }^{-1}$ observed in western Tanzania (Schwartz et al., 2002) and western Zimbabwe (Mudekwe, 2007), respectively. The absence of individuals in some middle and larger DBH classes for Pterocarpus angolensis and Milicia excelsa indicate discontinuous regeneration pattern, which is linked with regeneration failure in combination with illegal or selective harvesting of the species in the previous years (Poorter et al., 1996; Kacholi et al., 2015). The exploitation could be associated with the juxtaposition of the forest reserve to human settlements. The more the forest reserve is close to human settlements, the more it is subjected to substantial exploitation pressure resulting into lower tree density and broken regeneration (Mligo et al., 2011). Yet, regardless of the observed anomaly in the DBH class distribution for Pterocarpus angolensis, the harvesting rate of 2.8 stumps ha ${ }^{-1}$ was fairly lower compared to that of 4.0 stumps ha ${ }^{-1}$ and 7.7 stumps $^{-1}{ }^{-1}$ recorded in Nguru ya Ndege forest reserve (Modest et al., 2011) and western Tanzania (Schwartz et al., 2002), respectively. This small harvesting rate does not inevitably advocate lack of favoritism on harvesting of the species, rather it is due to unavailability of suitable trees for harvest as mature and straightest trees are the most valuable in timber market (Modest et al., 2011).

For Dalbergia melanoxylon, the observed density of $5.6 \mathrm{stems} \mathrm{ha}^{-1}$ was lower compared to the density of 8.5 stems

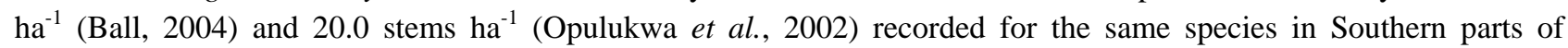
Tanzania. On the other hand, the density of Dalbergia melanoxylon was higher compared to the density of 3.1 stems $\mathrm{ha}^{-1}$ recorded in Nguru ya Ndege forest reserve. The harvesting rate of 1.2 stumps ha ${ }^{-1}$ for Dalbergia melanoxylon did not differ appreciably with that of 1.0 stumps ha ${ }^{-1}$ observed in Nguru ya Ndege forest reserve (Modest et al., 2011). The low harvesting rate, which is directly associated with lower number of the stems in the forest and gaps displayed in the DBH class distribution conclude that over-exploitation of the species occurred during the pasts. Moreover, absence of individuals in the lower DBH class suggests that the species could be suffering a population decline, hence poor 
regeneration (Lykke, 1998). This is also associated with human-induced disturbances, especially, illegal and/or selective logging (Kideghesho, 2015). Logging of big trees cause damage to sapling and seedling when trees fall down (Kacholi, 2015). Moreover, absence of abundant big trees for Dalbergia melanoxylon could be the cause for the lack of seedlings as establishment of seedlings depend largely on presence of abundant big ones (Jayakumar \& Nair, 2013). Apart from low seed availability or absence of seeds due to the removal of big trees, other factors like, high seed and seedling predation, presence of small sized canopy openings crated by removal of a single big tree, and the hasty invasion of logging gaps by herbaceous and lianas vegetation are commonly blamed for this lack of timber tree regeneration after selective logging (Stuart et al., 1990; Bedigian, 1998). The lack of individuals in lower DBH classes makes the future possibility of the species as commercial stock questionable as it can be eliminated from the forest. Although, Dalbergia melanoxylon was not reported to be in any immediate threat of extinction in Southern Tanzania (Ball, 2004), the lack of individuals in the lower size class in the Kimboza forest reserve provides robust evidence to raise some doubts on its long-term population's existence.

\section{CONCLUSION AND RECOMMENDATIONS}

In summary, all the four woody species were found facing anthropogenic exploitation. The exploitation has resulted in the observed low stems density for Milicia excelsa, Dalbergia melanoxylon and Pterocarpus angolensis. The DBH class distribution of Khaya anthotheca, Milicia excelsa and Pterocarpus angolensis revealed good regeneration, however, the last two species were hampered at larger size classes. Dalbergia melanoxylon displayed a poor regeneration indicating that the species is highly exploited, and gives no prospect of recovery in the near future as seedlings are lacking. Increased anthropogenic activities towards the forest resources are not only likely to cause extinction and adverse ecological effects to the ecosystem, but can also make the timber species commercially unavailable in the near future. Therefore, this study recommends for;

(a) Protection of the forest reserve by increasing regular patrol. This should be done by the responsible authority for the purpose of abolishing illegal harvest of the studied species and others, but also ensuring that future generation enjoy the nature and meet their needs.

(b) Provision of awareness and environmental education to the locals on the ecological importance of the species and forest at large. The locals should recognize that for any harm they are causing to the environment, they are causing misfortune to their future generation.

(c) Stringent measures should be institutionalized against illegal loggers and those found trading illegal logs of protected and non-protected timber species. The penalties of 30-1212 US dollars as fine for damage or 3 years of imprisonment for illegal loggers should be reviewed and possibly raised.

\section{ACKNOWLEDGEMENTS}

The author is thankful to the Dar es Salaam University College of Education (DUCE) and the Deutscher Akademischer Austausch Dienst (DAAD) for funding this study. The appreciations are also extended to the Morogoro Forest Department for permission to access the forest and providing technical.

\section{REFERENCES}

Ahrends A., Burgess N.D., Milledge S.A.H., Bulling M.T., Fisher B., Smart J.C.R., Clarke G.P., Mhoro B.E. \& Lewis S.L. (2010). Predictable waves of sequential forest degradation and biodiversity loss spreading from an African city. Proceedings of the National Academy of Sciences, 107(33): 14556-14561.

Ball S.M.J. (2004). Stocks and exploitation of East African blackwood Dalbergia melanoxylon: A flagship species for Tanzania's miombo woodlands? Oryx, 38(03): 266-272.

Becker C.D., Agreda A., Astudillo E., Costantino M. \& Torres P. (2005). Community-based Monitoring of Fog Capture and Biodiversity at Loma Alta, Ecuador Enhance Social Capital and Institutional Cooperation. Biodiversity and Conservation, 14(11): 2695-2707.

Bedigian D. (1998). Ecology of an African rain forest. Logging in Kibale and the conflict between conservation and exploitation. Economic Botany, 52(1): 87.

Borah N., Athokpam F.D., Garkoti S.C., Das A.K. \& Hore D.K. (2014). Structural and compositional variations in undisturbed and disturbed tropical forests of Bhuban hills in south Assam, India. International Journal of Biodiversity Science, Ecosystem Services \& Management, 10(1): 9-19.

Burgess N.D., Malugu I., Sumbi P., Kashindye A., Kijazi A., Tabor K., Mbilinyi B., Kashaigili J., Wright T.M., Gereau R.E., Coad L., Knights K., Carr J., Ahrends A. \& Newham R.L. (2017). Two decades of change in state, pressure and conservation responses in the coastal forest biodiversity hotspot of Tanzania. Oryx, 51(1): 77-86.

Chaudhary A., Burivalova Z., Koh L.P. \& Hellweg S. (2016). Impact of Forest Management on Species Richness: Global MetaAnalysis and Economic Trade-Offs. Scientific Reports, 6(1): 23954. 
FAO. (2010). Global forest resources assessment 2010: Main report. Food and Agriculture Organization of the United Nations.

FAO. (2018). Forests pathways to sustainable development. Food and Agriculture Organization of the United Nations.

Hill J.K., Gray M.A., Khen C.V., Benedick S., Tawatao N. \& Hamer K.C. (2011). Ecological impacts of tropical forest fragmentation: How consistent are patterns in species richness and nestedness? Philosophical Transactions of the Royal Society B: Biological Sciences, 366(1582): 3265-3276.

Jayakumar R. \& Nair K.K.N. (2013). Species Diversity and Tree Regeneration Patterns in Tropical Forests of the Western Ghats, India. ISRN Ecology, 2013: 1-14.

Kacholi D.S. (2013). Effects of habitat fragmentation on biodiversity of Uluguru Mountain Forests in Morogoro Region, Tanzania (Ph.D. Dissertation). Cuvillier Verlag Göttingen.

Kacholi D.S. (2015). Understory Tree Composition, Diversity and Natural Regeneration Status of Uluguru Forests in MorogoroTanzania. Journal of Education Humanities and Sciences, 4(1): 75-98.

Kacholi D.S. (2020). Density and Aboriginal Uses of Wild Tree Species in Milawilila Forest Reserve in Morogoro Region, Tanzania. Tanzania Journal of Science, 46(1): 85-100.

Kacholi D.S., Whitbread A.M. \& Worbes M. (2015). Diversity, abundance, and structure of tree communities in the Uluguru forests in the Morogoro region, Tanzania. Journal of Forestry Research, 26(3): 557-569.

Kideghesho J.R. (2015). Realities on Deforestation in Tanzania-Trends, Drivers, Implications and the Way Forward. In: M. Zlatic (Ed.) Precious Forests-Precious Earth. IntechOpen, [DOI: 10.5772/61002]

Liang J., Crowther T.W., Picard N., Wiser S., Zhou M., Alberti G., Schulze E.-D., McGuire A.D., Bozzato F., Pretzsch H., deMiguel S., Paquette A., Herault B., Scherer-Lorenzen M., Barrett C.B., Glick H.B., Hengeveld G.M. Nabuurs G.-J., Pfautsch S. \& Reich P.B. (2016). Positive biodiversity-productivity relationship predominant in global forests. Science, 354(6309): 89578957.

Lykke A.M. (1998). Assessment of species composition change in savanna vegetation by means of woody plants' size class distributions and local information. Biodiversity and Conservation, 7(10): 1261-1275.

Makana J.-R. \& Thomas S.C. (2006). Impacts of Selective Logging and Agricultural Clearing on Forest Structure, Floristic Composition and Diversity, and Timber Tree Regeneration in the Ituri Forest, Democratic Republic of Congo. Biodiversity and Conservation, 15(4): 1375-1397.

Mligo C., Lyaruu H. \& Ndangalasi H. (2011). The effect of anthropogenic disturbances on population structure and regeneration of Scorodophloeus fischeri and Manilkara sulcata in coastal forests of Tanzania. Southern Forests: A Journal of Forest Science, 73(1): 33-40.

Modest R., Maganga S., Hassan S., Mariki S. \& Muganda M. (2011). Population Structure and Exploitation of Three Commercial Tree Species in Nguru ya Ndege Forest Reserve, Morogoro - Tanzania. Ethiopian Journal of Environmental Studies and Management, 3(3):, 41-48.

Mudekwe J. (2007). The impact of subsistence use of forest products and the dynamics of harvested woody species populations in a protected forest reserve in western Zimbabwe, (Ph.D. Dissertation). Univeristy of Stellenbosch, 174 p.

Mwavu E.N. \& Witkowski E.T.F. (2009). Population structure and regeneration of multiple-use tree species in a semi-deciduous African tropical rainforest: Implications for primate conservation. Forest Ecology and Management, 258(5): 840-849.

Myers N., Mittermeier R.A., Mittermeier C.G., da Fonseca G.A.B. \& Kent J. (2000). Biodiversity hotspots for conservation priorities. Nature, 403(6772): 853-858.

Okiror P., Chono J., Nyamukuru A., Lwanga J.S., Sasira P. \& Diogo P. (2012). Variation in Woody Species Abundance and Distribution in and around Kibale National Park, Uganda. ISRN Forestry, 2012: 1-9.

Opulukwa M.J., Hamza K.F.S. \& Malende Y.H.M.B. (2002). Inventory of Dalbergia melanoxylon (Mpingo) in the southern part of Tanzania. The case of Nachingwea. African Study Monographs, 23(1): 1-10.

Poorter L., Bongers F., van Rompaey R.S.A.R. \& de Klerk M. (1996). Regeneration of canopy tree species at five sites in West African moist forest. Forest Ecology and Management, 84(1-3): 61-69.

Popradit A., Srisatit T., Kiratiprayoon S., Yoshimura J., Ishida A., Shiyomi M., Murayama T., Chantaranothai P., Outtaranakorn S. \& Phromma I. (2015). Anthropogenic effects on a tropical forest according to the distance from human settlements. Scientific Reports, 5(1): 14689.

Riswa, S, \& Hartant, L. (1995). Human impacts on tropical forest dynamics. Vegetatio, 121(1-2): 41-52.

Schwartz M.W., Caro T.M. \& Banda-Sakala T. (2002). Assessing the sustainability of harvest of Pterocarpus angolensis in Rukwa Region, Tanzania. Forest Ecology and Management, 170(1-3): 259-269.

Sharma P., Thapa R.B. \& Matin M.A. (2020). Examining forest cover change and deforestation drivers in Taunggyi District, Shan State, Myanmar. Environment, Development and Sustainability, 22: 5521-5538.

Stuart S.N., Adams R.J. \& Jenkins M. (1990). Biodiversity in sub-Saharan Africa and its islands: Conservation, management, and sustainable use. IUCN.

Temu R.P.C. \& Andrew S.M. (2008). Endemism of plants in the Uluguru Mountains, Morogoro, Tanzania. Forest Ecology and Management, 255(7): 2858-2869. 